\begin{tabular}{|c|c|}
\hline C & $\begin{array}{c}\text { International Journal of Current Research } \\
\text { and Academic Review }\end{array}$ \\
\hline $\begin{array}{l}\text { XCELLENT } \\
\text { UBLISHERS } \\
\end{array}$ & $\begin{array}{r}\text { ISSN: 2347-3215 (Onlin } \\
\text { Journal }\end{array}$ \\
\hline
\end{tabular}

\title{
Screening and Optimization of Filamentous Fungi for Extracellular Lipase Production from Various Soil Samples Taken In and Around Shimla (HP), India
}

\author{
Gaurav Kumar*, Sameer Singh Faujdar, Priya Mehrishi and Shikha Sharma
}

Department of Microbiology, Maharishi Markandeshwar Medical College and Hospital, Kumarhatti, Solan, Himachal Pradesh, 173229, India

*Corresponding author

\begin{abstract}
In the present study samples were collected from different sources such as oil contaminated soil (railway station), moist soil, barren land, garden soils and humus, near dairy and other soil samples in and around Shimla. FromTotal of 48 isolates were isolated from different samples, out of which four were selected on the basis of zone of hydrolysis on tributyrin-agar plates. Among these four isolates, Isolate -3 (Aspergillus niger) gave maximum production of lipase. Further the optimization of production and reaction conditions were carried out. Enzyme gave maximum activity in M3 medium with an inoculum size of $3.6 \times 10^{5}$ spores, at incubation time of $72 \mathrm{~h}$. The enzyme gave considerable amount of activity with maltose and peptone as carbon and nitrogen source respectively at a concentration of $2.0 \%$ each at $\mathrm{pH} 8.0$, temperature of $40^{\circ} \mathrm{C}$ and $150 \mathrm{rpm}$. During the optimization of reaction conditions, the most favorable reaction conditions was found to be $40^{\circ} \mathrm{C}$ temperature for 15 minutes of incubation and it was observed that the enzyme showed maximum enzyme activity i.e. $4.3 \mathrm{U} / \mathrm{mL}$ with Tris $\mathrm{HCl}$ buffer $(40 \mathrm{mM})$ of $\mathrm{pH}$ 8.0. A 2.17 fold increase in activity of lipase from fungal Isolate -3 (Aspergillus niger) was observed after optimization of culture and reaction conditions.
\end{abstract}

\section{Article Info}

Accepted: 28 December 2016

Available Online: 10 January 2017

\author{
Keywords \\ Extracellular Lipase, \\ Aspergillus niger, \\ Soil samples, \\ Tributyrin Agar, \\ Potato dextrose agar.
}

\section{Introduction}

Enzymes are considered as nature's catalysts. Lipase (triacylglycerol acylhydrolases) (EC 3.1.1.3) catalyses hydrolysis of long chain acyl glycerol at an oil water interface. These are enzymes belonging to the group of hydrolases that present as main biological function to catalyze the hydrolysis of insoluble triacylglycerols to generate free fatty acids, mono and diacylglycerols and glycerol (Lutz, 2004, Kempka et al., 2008). Ester synthesis is carried out in aqueous media in the presence of various lipases (Lacointe et al., 1996). Lipases are widely distributed in microorganisms, plants, and animal tissues (Pahoja and Sethar, 2002; Pratuangdejkul and Dharmsthiti, 2000). Among them, microorganisms are the most important source of lipases for their diverse properties (Hasan et al. 2006). Filamentous fungi are known to be good lipase producers; examples are Aspergillus niger (Mahadik et al., 2002), Fusarium solani (Maia et al., 2001), Rhizopus oligosporus (Ul-Haq et al., 2002) and members of the genera Geotrichum, Mucor and Penicillium (Sharma et al., 2001). The production of enzymes by microorganisms as well as the enzyme yield depends on the nutritional factors 
especially carbon and nitrogen sources and physicochemical parameters such as initial $\mathrm{pH}$, incubation temperature and incubation time (Mukesh et al., 2012a, 2012b). Lipases have many uses, including acceleration of cheese curing and others in the food industry (Sharma et al., 2001; Hasan et al., 2006), the separation of racemic mixtures (Rao et al., 1993), detergent production (Hasan et al., 2006) effluent treatment (Castro et al., 2004; Mendes and Castro 2005; Rosa et al., 2006), and the production of cosmetics and pharmaceuticals (Elibol and Ozer, 2000). Interest in lipase enzyme has been greatly developed in the last few years due to their potential applications. They are extensively used in fat hydrolysis as well as in synthesis of triacylglycerol. Lipases are also used in various reactions due to their high specificity, prevention of product and substrate deterioration and decreased energy consumption. The advantage of the enzymatic hydrolysis over the chemical process is less energy requirements and higher quality of the obtained products (Ionita et al., 2001).

\section{Materials and Methods}

This study was conducted from January 2014 to June 2014 at Department of Biotechnology, Himachal Pradesh University, Shimla (HP). Total 48 soil samples were collected with the help of soil auger, from different sources such as oil contaminated soil (railway station), moist soil, barren land, garden soils and humus, near dairy and other soil samples in and around Shimla. All the different types of soils were sieved to avoid roots, stones, dry leaves, and other unwanted materials and were air dried. Ten gram of soil samples were collected using a sterile spatula in a sterile Petri plate. For wet and humid soil the trays were exposed to the sunlight till the time the soil got adequately dried. The soil samples were brought to the laboratory and processed immediately. Ten gram of dried processed soil was mixed with $100 \mathrm{ml}$ of sterile distilled water in a conical flask of $250 \mathrm{ml}$ and was shaken well. This homogeneous soil suspension is referred to as stock suspension.

Chemicals and reagents - Potato dextrose agar (PDA), Tributyrin, $\mathrm{K}_{2} \mathrm{HPO}_{4}, \mathrm{KH}_{2} \mathrm{PO}_{4}, \mathrm{KCl}, \mathrm{MgSO}_{4} .7 \mathrm{H}_{2} \mathrm{O}$, $\mathrm{NH}_{4} \mathrm{Cl}$, Yeast Extract, $p$-nitrophenylpalmitate ( $p$-NPP), $p$-nitrophenol ( $p$-NP), Tween 80, Tris buffer, Peptone, Glucose, $\mathrm{NaCl}$, Beef Extract, Olive oil, Isopropanol, Agar, $\mathrm{KCl}$, Phenol Red, Lactophenol, Potato dextrose broth, $\mathrm{NaH}_{2} \mathrm{PO}_{4}$ etc. All the chemicals were of analytic grade and were used as received.
Isolation of lipolytic fungi - $1 \mathrm{~mL}$ each of sample was serially diluted $10^{-1}$ to $10^{-10}$ times in sterile saline. $100 \mu \mathrm{L}$ of each of the dilution was spread over PDA at $\mathrm{pH} 7.0$ and was incubated at $37^{\circ} \mathrm{C}$ for $48-72$ hours. The isolated distinct colonies were carefully picked up depending upon different shape, size, colour and pure line cultures were established by repeatedly streaking single distinct colonies on fresh PDA plates. Pure culture/colonies were maintained on PDA plates for further work. Tween 80 and tributyrin agar plates were used for the isolation of lipolytic fungi.

Screening of lipase producing fungi - PDA plates containing Tween 80 and tributyrin were used for screening of lipase producing fungal isolates. The lipolytic activity was indicated by the appearance of a visible precipitate, resulting from the deposition of crystals of the calcium salt formed by the fatty acid liberated by the enzyme, or as a clearing of such a precipitate around a colony due to complete degradation of the salt of the fatty acid (Kim et al., 2001).

Inoculum preparation - Spores were collected from three to four days old cultures grown on PDA plates using sterilized inoculation loop in $2 \mathrm{~mL}$ of sterile buffer saline containing $0.01 \%$ Tween 20 . Spore concentration was determined by counting spores with a haemocytometer.

Production of lipase - The production medium containing Peptone $1.5 \%, \mathrm{NaCl} 0.5 \%, \mathrm{CaCl}_{2} 0.1 \%$ and Tween $801 \%$ ( Sneath et al.,1986) was autoclaved at 15 $\mathrm{lb} / \mathrm{inch}^{2}$ pressure at $121^{\circ} \mathrm{C}$ for $15 \mathrm{~min}$ and cooled at room temperature. The sterile production medium $(50 \mathrm{~mL}$ in $250 \mathrm{~mL}$ Erlenmeyer flask) was inoculated with $2.4 \times 10^{5}$ spores and incubated at $37^{\circ} \mathrm{C}$ for 3 days. The fermentation broth was collected to assay lipase activity. The culture broth was analyzed for lipase activity.

Assay of lipase- Lipase activity was assayed by the method given by Winkler and Stuckmann in 1979 by measuring the micromoles of $p$-nitrophenol released from $p$-nitrophenylpalmitate.

Procedure - $2.9 \mathrm{~mL}$ of Tris- $\mathrm{HCl}$ buffer $(0.1 \mathrm{M}, \mathrm{pH} 7)$ was incubated in water bath at $37^{\circ} \mathrm{C}$ for 10 minutes. Then $60 \mu \mathrm{l}$ of the substrate ( $p$-NPP, $20 \mathrm{mM}$ ) was added to the pre-warmed buffer and incubated again at $37^{\circ} \mathrm{C}$ for 10 minutes. To the pre-warmed solution, $40 \mu \mathrm{l}$ of enzyme was added and incubated again at $37^{\circ} \mathrm{C}$ for 10 minutes. The reaction was stopped by chilling at $-20^{\circ} \mathrm{C}$. The amount of $p$-Nitrophenol released was measured at 
$410 \mathrm{~nm}$ (LabIndia UV/VIS Spectrophotometer Lambda 12) after bringing the tubes to room temperature. A standard curve of $p$-NP was plotted at the selected concentration $(0.5-50 \mu \mathrm{g} / \mathrm{mL})$. The readings were taken in triplicates and the strain showing the highest activity was selected for further study.

Lipase activity - One unit of lipase activity was defined as amount of enzyme required to release one micromole of $p$-NP from the substrate ( $p$-NPP) per minute of the enzyme preparation under standard assay conditions.

\section{Optimization of production parameters for} extracellular lipase from selected fungal isolate -

Various production parameters such as production medium, inoculum size, incubation time, carbon source and its concentration, nitrogen source and its concentration, $\mathrm{pH}$, temperature and agitation rate were optimized to get maximum production of the Lipase enzyme.

Screening of media for extracellular lipase production- The selected isolate was grown in five different production media (M1-M5) reported by previous workers (Table 1).

Optimization of inoculum size - Inoculum size was optimized by inoculating the production medium with varying spore count i.e. $1.2 \times 10^{5}, 2.4 \times 10^{5}, 3.6 \times 10^{5}$, $4.8 \times 10^{5}, 6.0 \times 10^{5}$ spores and incubating it for $48 \mathrm{~h}$. Filtered broth was assayed for enzyme activity.

Effect of incubation time on lipase production To study the optimal incubation time for the production of enzyme, the production medium was incubated with optimized inoculum size in the shaker for the time intervals of $24 \mathrm{~h}, 48 \mathrm{~h}, 72 \mathrm{~h}, 96 \mathrm{~h}, 120 \mathrm{~h}$ and $144 \mathrm{~h}$. The culture broth was assayed for enzyme activity.

Effect of carbon source on the production of lipase Various carbon sources such as Sucrose, Glucose, Maltose and Galactose were used in the production medium at a concentration of $1 \%(\mathrm{w} / \mathrm{v})$ to check the effect of carbon source on lipase production. The medium without carbon source served as the control. The culture supernatants were assayed for enzyme activity.

Effect of carbon source concentration on lipase production - To optimize the concentration of selected carbon source for maximal enzyme production, different concentrations of optimized carbon source $[0.5$,
$1.0,1.5,2.0,2.5$ and $3.0 \%(\mathrm{w} / \mathrm{v})]$ were used in the production medium and the culture supernatant was assayed for enzyme activity.

Effect of nitrogen source on lipase production - The effect of various nitrogen sources on the production of enzyme was studied by adding $1 \% \mathrm{w} / \mathrm{v}$ of Yeast extract, Peptone, Ammonium chloride, Sodium nitrate, Glycine, Beef extract, Casein, Tyrosine and Arginine to the production medium and incubating the medium at culture conditions optimized previously. The medium without nitrogen source served as the control.

Effect of concentration of nitrogen source on the production of lipase -To optimize the concentration of selected nitrogen source for maximal enzyme production, different concentrations $[0.5,1.0,1.5,2.0$ and $2.5 \%(\mathrm{w} / \mathrm{v})]$ were used in the production medium and the culture supernatant was assayed for enzyme activity.

Effect of $\mathrm{pH}$ of the medium on the production of lipase - For the optimization of production $\mathrm{pH}$ the production medium of varying $\mathrm{pH}$ viz. 4.0, 5.0, 6.0, 7.0, 8.0, 9.0 and 10.0 was inoculated with the culture and incubated in the rotary shaker for $72 \mathrm{~h}$ at $37^{\circ} \mathrm{C}$ and lipase activity was determined.

Effect of incubation temperature on lipase production - The most favourable production temperature was studied by incubating the productionmedium at different temperatures i.e. $25^{\circ} \mathrm{C}, 30^{\circ} \mathrm{C}, 35^{\circ} \mathrm{C}, 40^{\circ} \mathrm{C}, 45^{\circ} \mathrm{C}$ and $50^{\circ} \mathrm{C}$. The enzyme activity was checked by using the standard assay method described previously.

Effect of agitation rate on lipase production - For the optimization of agitation rate for the maximum enzyme production the enzyme was agitated at different rpm (rotations per minute) i.e. $50 \mathrm{rpm}, 100 \mathrm{rpm}, 150 \mathrm{rpm}, 200$ $\mathrm{rpm}$ and $250 \mathrm{rpm}$.

Optimization of reaction parameters for maximum activity of extracellular lipase from selected fungal isolate -

Various reaction parameters such as Effect of reaction time,reaction temperature, different buffer systems,molarity of buffer andbuffer $\mathrm{pH}$ on lipase activity were optimized to get maximum production of the Lipase enzyme. 
Effect of reaction time on lipase activity - To study the effect of reaction time, enzyme was incubated in reaction medium for different time intervals $(5,10,15,20$ and 25 min) with $20 \mathrm{mM}$ substrate ( $p$-NPP) and Tris buffer $(0.1 \mathrm{M})$ of $\mathrm{pH} 7.0$. The reaction was performed using 40 $\mu l$ of crude enzyme at $37^{\circ} \mathrm{C}$ incubation temperature.

Effect of reaction temperature on lipase activity - To study the effect of reaction temperature, enzyme activity was assayed at various reaction temperatures $(25,30,35$, 40,45 and $50^{\circ} \mathrm{C}$ ) with $20 \mathrm{mM}$ substrate $p$-NPP and Tris buffer $(0.05 \mathrm{M})$ of $\mathrm{pH} 7.0$. The reaction was performed using $40 \mu \mathrm{l}$ of crude enzyme for optimized reaction time.

\section{Effect of different buffer systems on lipase activity -} Following buffers were screened for enzyme activity

- $50 \mathrm{mM}$ Sodium citrate buffer ( $\mathrm{pH} 5.0)$

- $50 \mathrm{mM}$ Potassium phosphate buffer (pH 7.0)

- $50 \mathrm{mM}$ Sodium phosphate buffer (pH 7.0)

- 50 mMTris-HCl buffer (pH 8.0)

Effect of molarity of buffer on lipase activity Selected buffer with different molarity i.e. 10, 20, 30, 40 and $50 \mathrm{mM}$ was used to perform enzyme reaction.

Effect of buffer pH on lipase activity - Selected buffer with different $\mathrm{pH}$ range $(6.0,7.0,8.0,9.0$ and 10.0) was used and the activity of lipase evaluated for each.

\section{Results and Discussion}

48 fungal cultures were isolated from different soil samples. Out of them four culture isolate showed zone of hydrolysis on tributyrin-agar plates and were shifted to PDA plates. Identification of fungus was done on the basic of colony morphology on PDA plate and Lactophenol cotton blue mount (Jagdish Chander, 2009).

Four isolates were screened quantitatively through shake flask fermentation (Table 2). It was found that production of lipases ranged from $0.54 \mathrm{U} / \mathrm{mL}$ to 1.98 $\mathrm{U} / \mathrm{mL}$. Out of the four strains tested the strain designated as isolate -3 (Aspergillus niger) from soil sample from railway station, Shimla gave the maximum production of extracellular lipase $(1.98 \mathrm{U} / \mathrm{mL})$.

\section{Optimization of culture conditions for the production of extracellular lipase}

The optimization of culture conditions was done for the maximum production of extracellular lipases.
Media optimization - Among the 5 media tested, the maximum production of extracellular lipase $(1.98 \mathrm{U} / \mathrm{mL})$ was observed in Medium 3 (M 3) (Table 3). Lowest lipase activity of $0.54 \mathrm{U} / \mathrm{mL}$ was observed in Medium 4 (M 4). The reason for higher yield in $\mathrm{M} 3$ might be due to the fact that glucose, $\mathrm{NH}_{4} \mathrm{Cl}$ and $\mathrm{K}_{2} \mathrm{HPO}_{4}$ are easily metabolizable carbon, nitrogen, and potassium source respectively (Elibol and Ozer 2000).

Optimization of inoculum size - The inoculum of size $3.6 \times 10^{5}$ spores showed the maximum enzyme production with an enzyme activity of $2.14 \mathrm{U} / \mathrm{mL}$ (Figure 1 and Table 5). It might be due to adequate amount of mycelium produced, which synthesize optimum level of enzyme. As the dose of inoculum increased there was gradual decrease of lipase activity. It might be due to the reason that it consumed majority of the substrate for growth and metabolic processes, hence enzyme synthesis decreased. In a study by (Mathew et al., 2008) inoculum of size $4.5 \times 10^{7}$ spores $/ \mathrm{mL}$ gave the maximum enzyme production in Penicilliumsp. Another study showed $3.6 \times 10^{5}$ spores $/ \mathrm{mL}$ as the optimum inoculum size for lipase production from Penicilliumcyclopium (Vanotet al., 2002).

Effect of incubation time on lipase production Optimal incubation time for maximum enzyme production was found to be $72 \mathrm{~h} \quad(2.32 \mathrm{U} / \mathrm{mL})$ (Figure 2 ). There was considerable enzyme activity till upto 120 $h$ of incubation even though it was lower than $72 \mathrm{~h}$ growth. After this it started decreasing, this might have been due to the exhaustion of nutrients, which may lead to the accumulation of toxic products and decreased production of enzyme. It is evident from the results that time course of enzyme production plays a very critical role in enzyme synthesis (Sztajar and Maliszewska, 1988). In another study, 4 days of incubation time was optimized for lipase from Rhizopus oryzae (Hiolet al., 2000).

Effect of carbon source on production of lipase production - Maximum production of extracellular lipase was obtained from the medium which was supplemented with maltose (1\%) as carbon source giving enzyme activity of $2.39 \mathrm{U} / \mathrm{mL}$ (Figure 3). Aspergillus niger and Aspergillus terreus showed maximum lipase production when corn oil (0.4\%) was used as carbon source (Abdel-Fattah and Hammad, 2002). Candida rugosa lipase gave maximum activity when glucose was used as carbon source in a study carried out by (Fadiloglu and Erkmen, 2002). 
Effect of carbon source concentration on lipase production - The various concentrations of maltose were used in the production medium and $2.0 \%(\mathrm{w} / \mathrm{v})$ was optimized to give enzyme activity of $2.95 \mathrm{U} / \mathrm{mL}$ (Figure 4). There was a consistent decrease in lipase activity when the concentration of maltose increased or reduced from $2 \%$, therefore $2 \%$ of maltose was taken as optimum for further studies. In a previous study, $1.25 \%$ of Glucose concentration was found to be the optimum for the production of lipase from Geotrichum candidum (Gopinath et al., 2003). In another study, 1\% of soluble starch as carbon source gave maximum production of lipase in Saccharomyces cerevesiae (Sherazi et al., 1998).
Effect of nitrogen source on lipase production Among the various nitrogen sources used, organic nondefined nitrogen sources were found to enhance the enzyme production (Figure 5). This might be because of other nutrients and growth enhancers present in them. The enzyme production reached to $(3.03 \mathrm{U} / \mathrm{mL})$ maximum when peptone $(1 \% \mathrm{w} / \mathrm{v})$ was used as the nitrogen source. In a previous study, yeast extract was shown as the best nitrogen source for the production of lipase from Rhizopus delemar (Espinosa et al., 1990). In a study carried out on Aspergillus sp. peptone as nitrogen source gave maximum lipase production (Cihangir and Sarikaya 2004).

Table 1. Composition of the media used

\begin{tabular}{|c|c|c|c|}
\hline Media & Components & Concentration (\%) & Reference \\
\hline M 1 & $\begin{array}{c}\text { Glucose } \\
\text { Peptone } \\
\mathrm{MgSO}_{4} \\
\mathrm{~K}_{2} \mathrm{HPO}_{4} \\
\text { Peppermint oil }\end{array}$ & $\begin{array}{c}0.1 \\
0.5 \\
0.01 \\
0.1 \\
1.0\end{array}$ & $\begin{array}{l}\text { (Kekde and Chavan } \\
\text { 2011) }\end{array}$ \\
\hline M 2 & $\begin{array}{c}\mathrm{KH}_{2} \mathrm{PO}_{4} \\
\mathrm{MgSO}_{4} 7 \mathrm{H}_{2} \mathrm{O} \\
\mathrm{KCl} \\
\text { Yeast extract } \\
\text { Peptone } \\
\text { Glucose } \\
\text { Olive oil } \\
\end{array}$ & $\begin{array}{c}0.2 \\
0.05 \\
0.05 \\
0.025 \\
0.025 \\
1.25 \\
1.2 \\
\end{array}$ & (Sharma et al.,2012) \\
\hline M 3 & $\begin{array}{c}\text { Glucose } \\
\text { Olive oil } \\
\mathrm{NH}_{4} \mathrm{Cl} \\
\text { Yeast extract } \\
\mathrm{K}_{2} \mathrm{HPO}_{4} \\
\mathrm{MgCl}_{2} \\
\mathrm{CaCl}_{2} \\
\end{array}$ & $\begin{array}{c}0.1 \\
3.0 \\
0.5 \\
0.36 \\
0.1 \\
0.01 \\
0.2 \\
\end{array}$ & (Gupta et al., 2004) \\
\hline M 4 & $\begin{array}{c}\mathrm{NaH}_{2} \mathrm{PO}_{4} \\
\mathrm{KH}_{2} \mathrm{PO}_{4} \\
\mathrm{MgSO}_{4} 7 \mathrm{H}_{2} \mathrm{O} \\
\mathrm{CaCl}_{2} \\
\text { Ammonium sulphate } \\
\text { Olive oil }\end{array}$ & $\begin{array}{c}0.12 \\
0.2 \\
0.03 \\
0.025 \\
1 \\
2\end{array}$ & (Colenet al., 2006) \\
\hline M 5 & $\begin{array}{c}\text { Peptone } \\
\mathrm{NaCl} \\
\mathrm{CaCl}_{2} \\
\text { Tween } 80\end{array}$ & $\begin{array}{c}1.5 \\
0.5 \\
0.1 \\
1 \\
\end{array}$ & (Sneathet al.,1986) \\
\hline
\end{tabular}


Table.2 Extracellular lipase activity shown by different isolates

\begin{tabular}{|l|c|}
\hline \multicolumn{1}{|c|}{ Isolates } & Lipase activity (U/mL) \\
\hline Isolate-1 (Penicillium species) & 1.32 \\
\hline Isolate -2 (Aspergillus fumigatus) & 1.36 \\
\hline Isolate -3 (Aspergillus niger) & $\mathbf{1 . 9 8}$ \\
\hline Isolate -4 (Rhizopus species) & 0.54 \\
\hline
\end{tabular}

Table.3 Effect of different media on production of extracellular lipase

\begin{tabular}{|c|c|}
\hline Name of medium & Enzyme activity (U/mL) \\
\hline M 1 & 0.35 \\
\hline M 2 & 1.36 \\
\hline M 3 & $\mathbf{2 . 0 8}$ \\
\hline M 4 & 0.54 \\
\hline M 5 & 1.98 \\
\hline
\end{tabular}

Table.4 Effect of agitation rate on lipase production of Isolate -3 (Aspergillus niger)

\begin{tabular}{|c|c|}
\hline Agitation rate (rpm) & Lipase activity (U/mL) \\
\hline 50 & 0.56 \\
\hline 100 & 2.87 \\
\hline $\mathbf{1 5 0}$ & $\mathbf{3 . 9 6}$ \\
\hline 200 & 3.19 \\
\hline 250 & 1.58 \\
\hline
\end{tabular}

Fig.1 Effect of inoculum size on the production of lipase of Isolate -3 (Aspergillus niger)

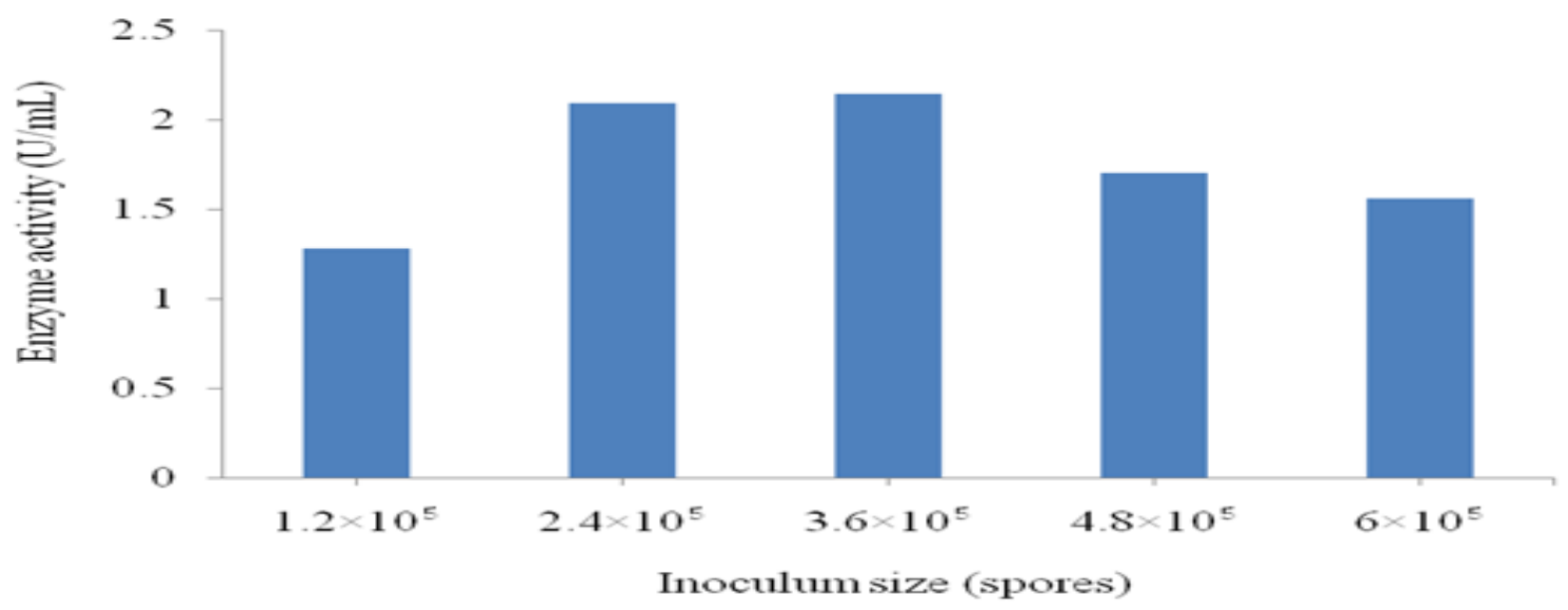


Fig.2 Effect of incubation time on lipase production of Isolate -3 (Aspergillus niger)

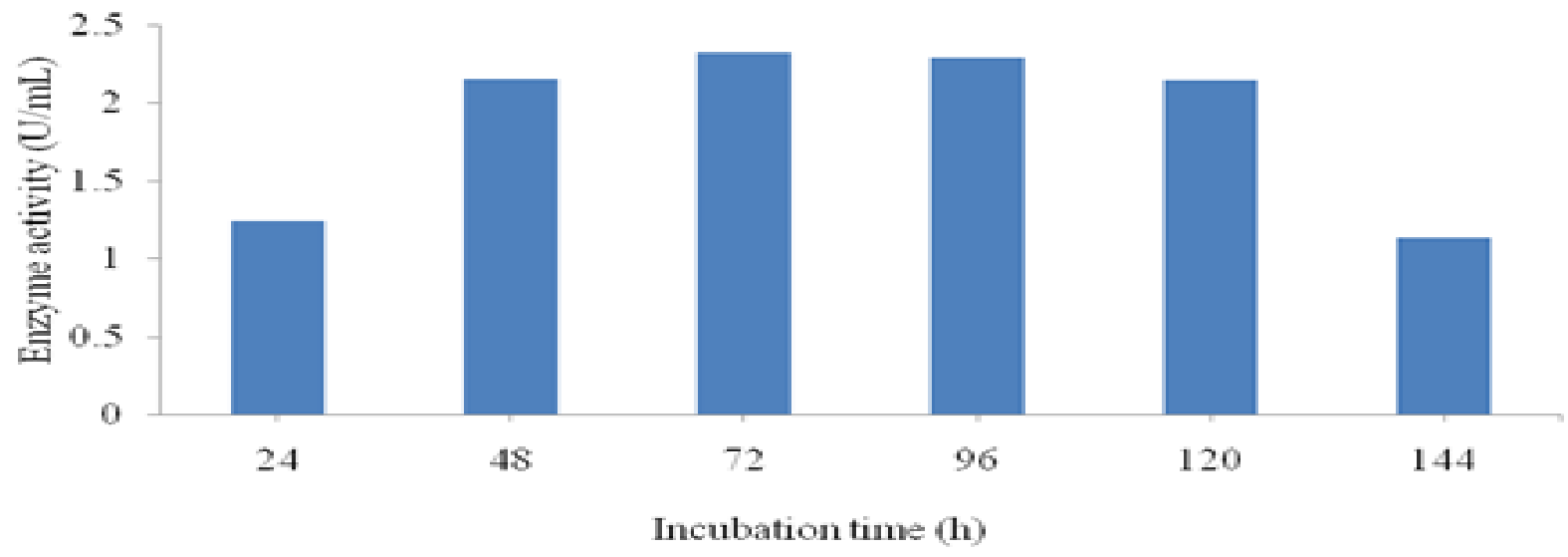

Fig.3 Effect of different carbon sources on lipase production of Isolate -3 (Aspergillus niger)

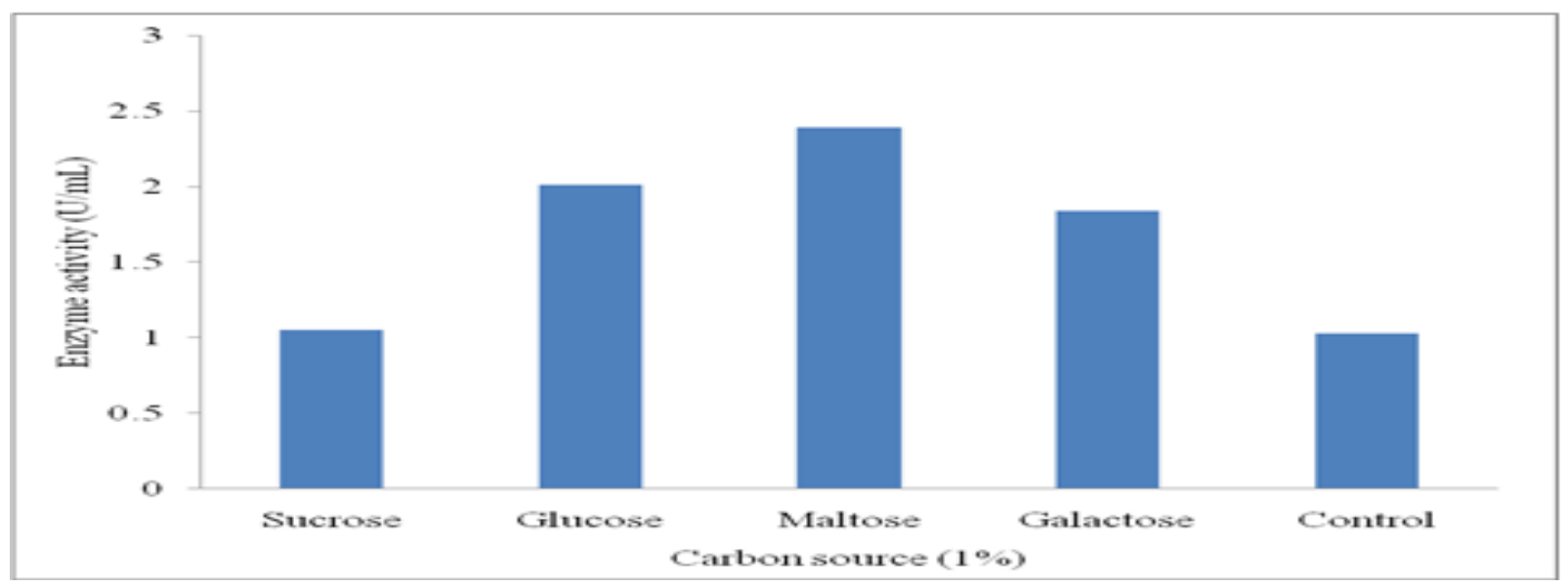

Fig.4 Effect of different concentrations of maltose on lipase production of Isolate -3 (Aspergillus niger)

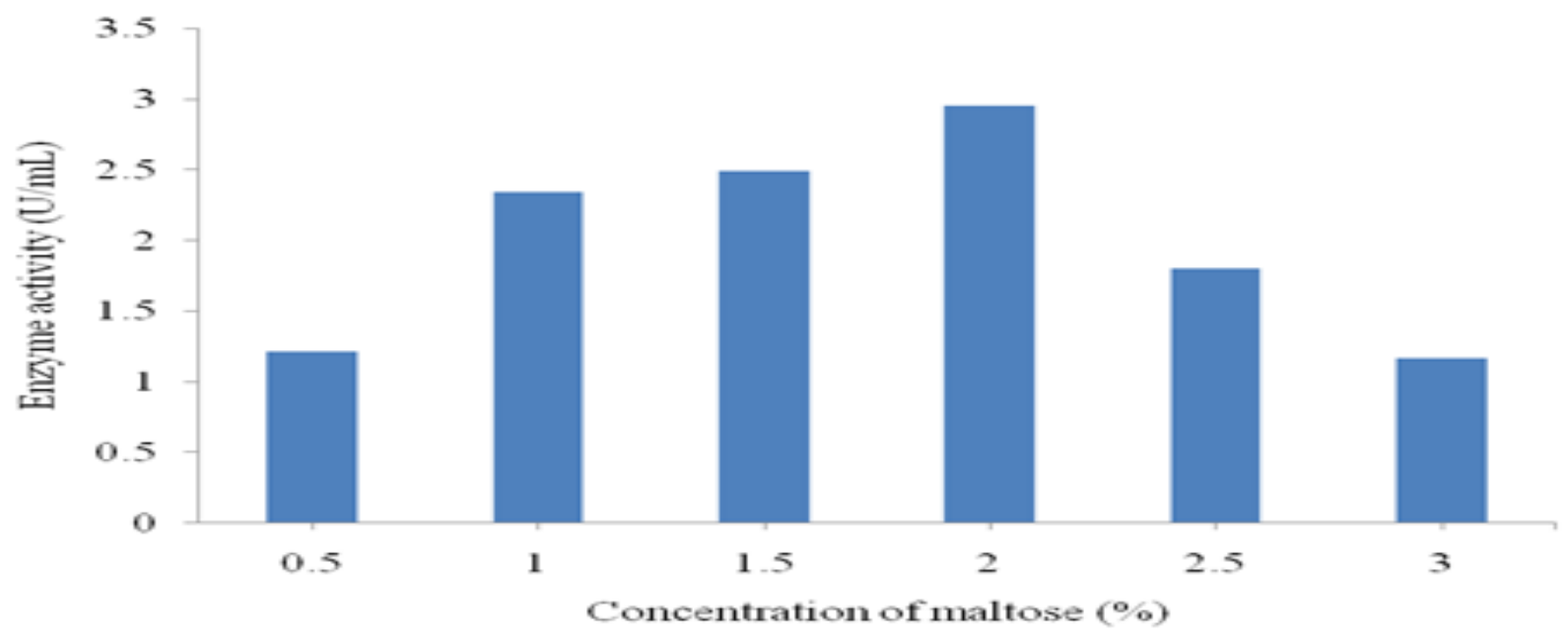


Fig.5 Effect of different nitrogen sources on the lipase production of Isolate -3 (Aspergillus niger)

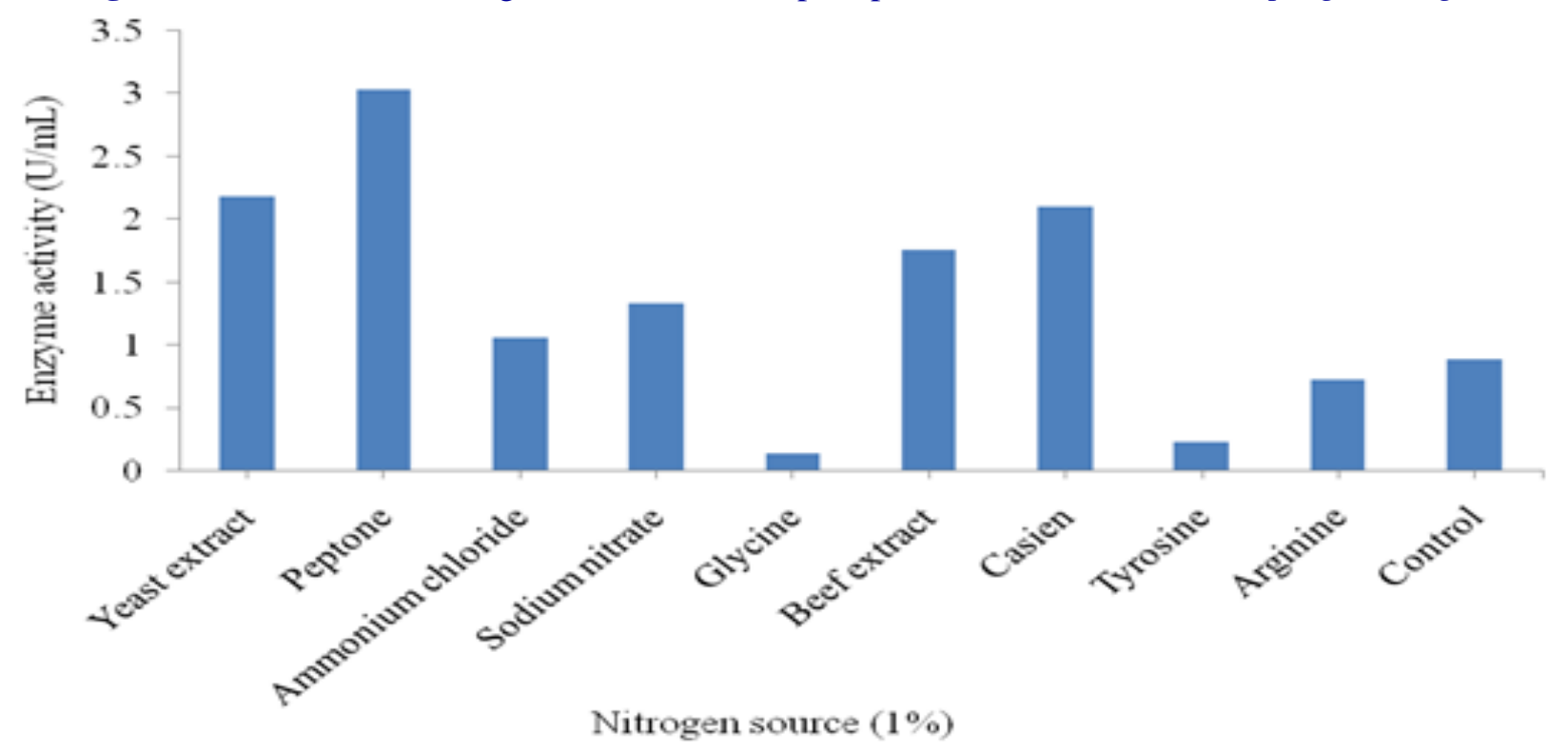

Fig.6 Effect of concentration of peptone on lipase production of Isolate -3 (Aspergillus niger)

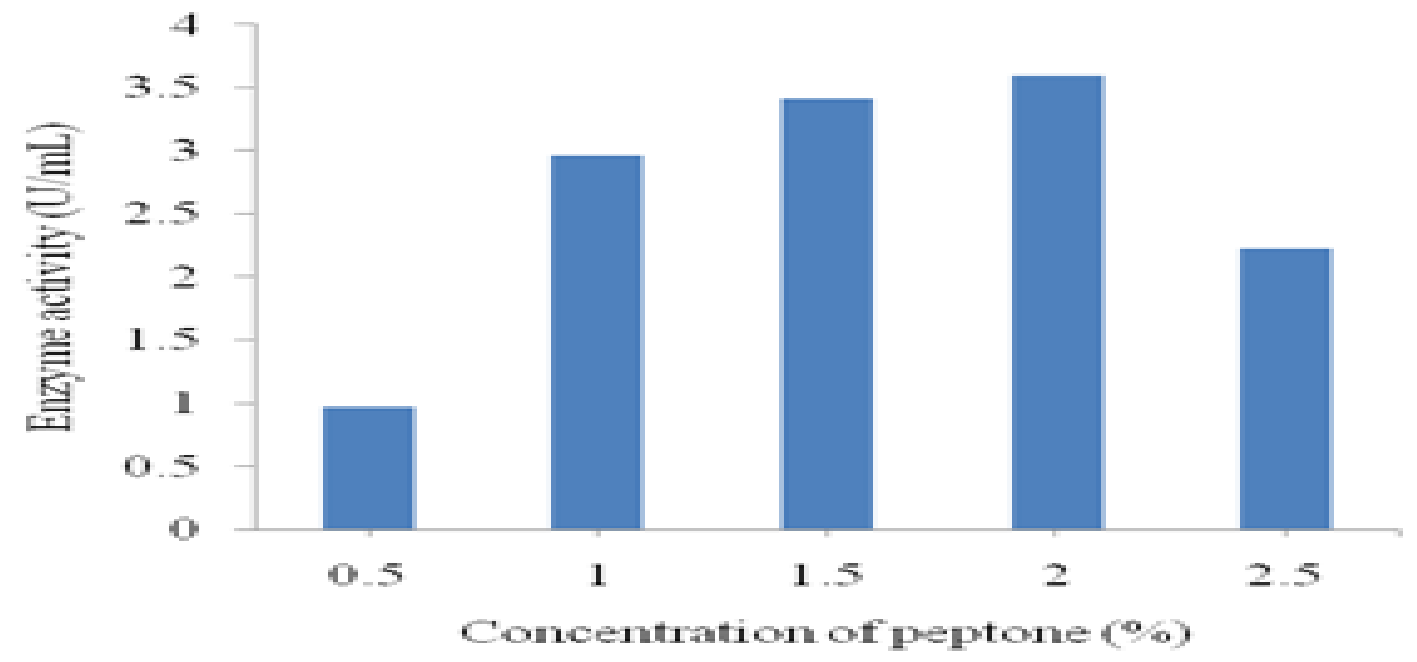

Fig 7. Effect of different $\mathrm{pH}$ on the lipase production of Isolate -3 (Aspergillus niger)

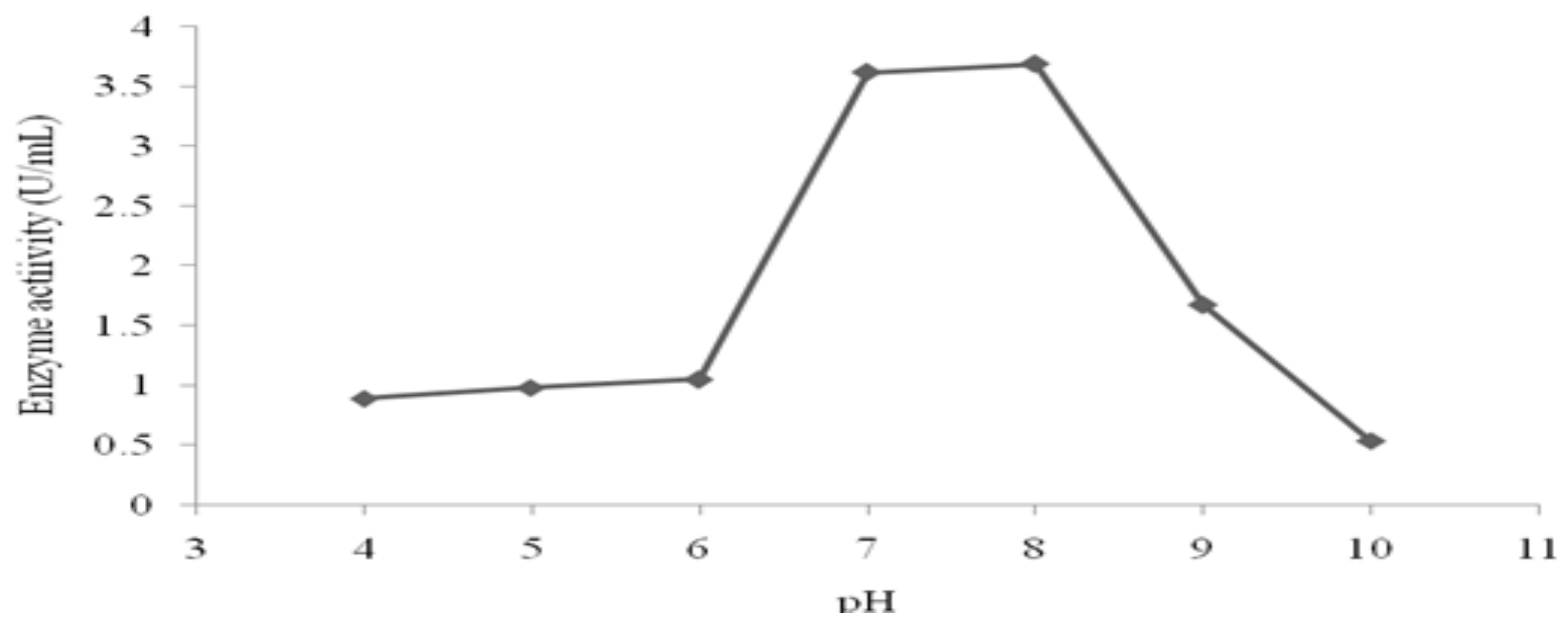


Fig.8 Effect of incubation temperature on the lipase production of Isolate -3 (Aspergillus niger).

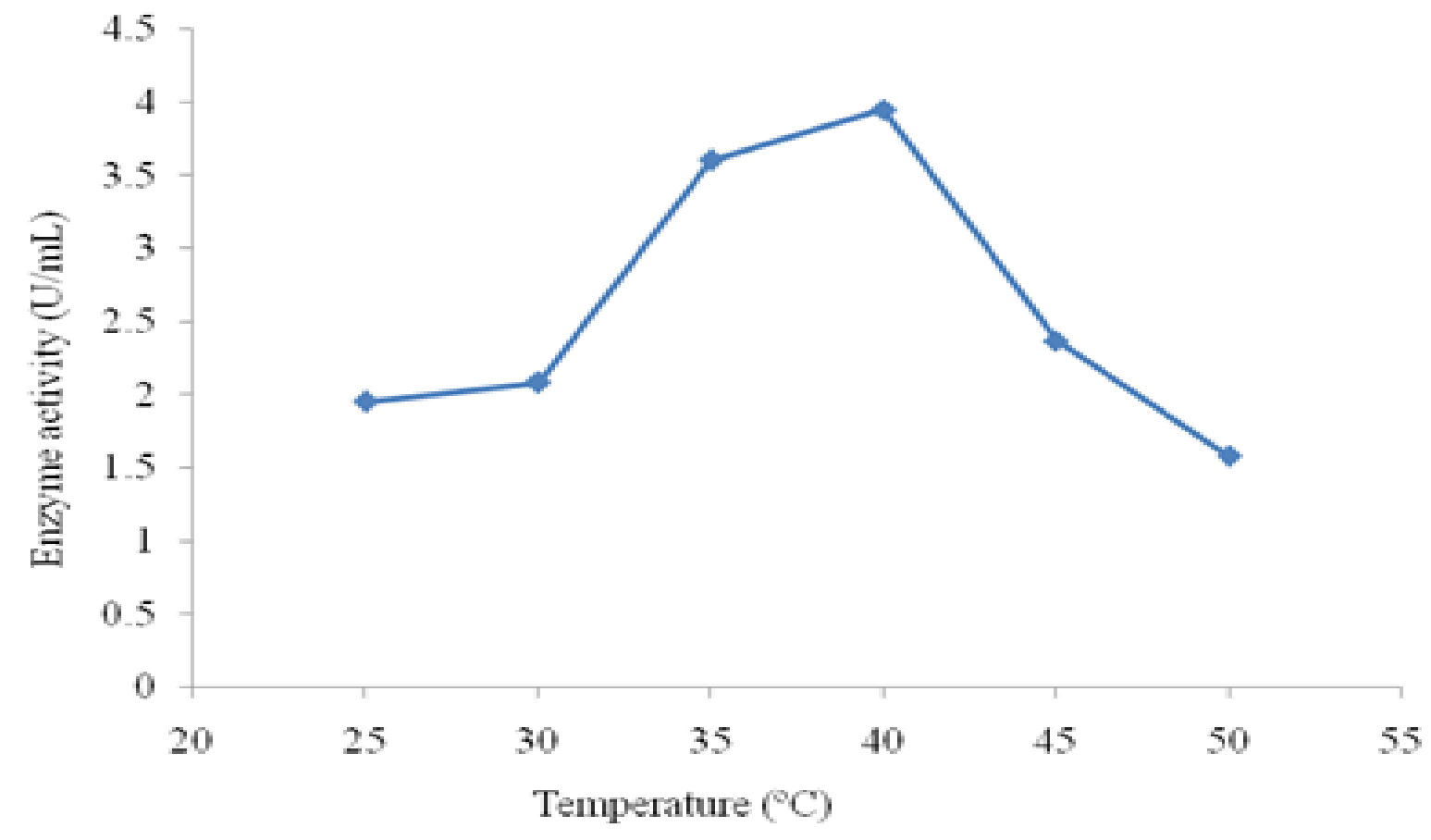

Fig.9 Effect of incubation time on lipase activity

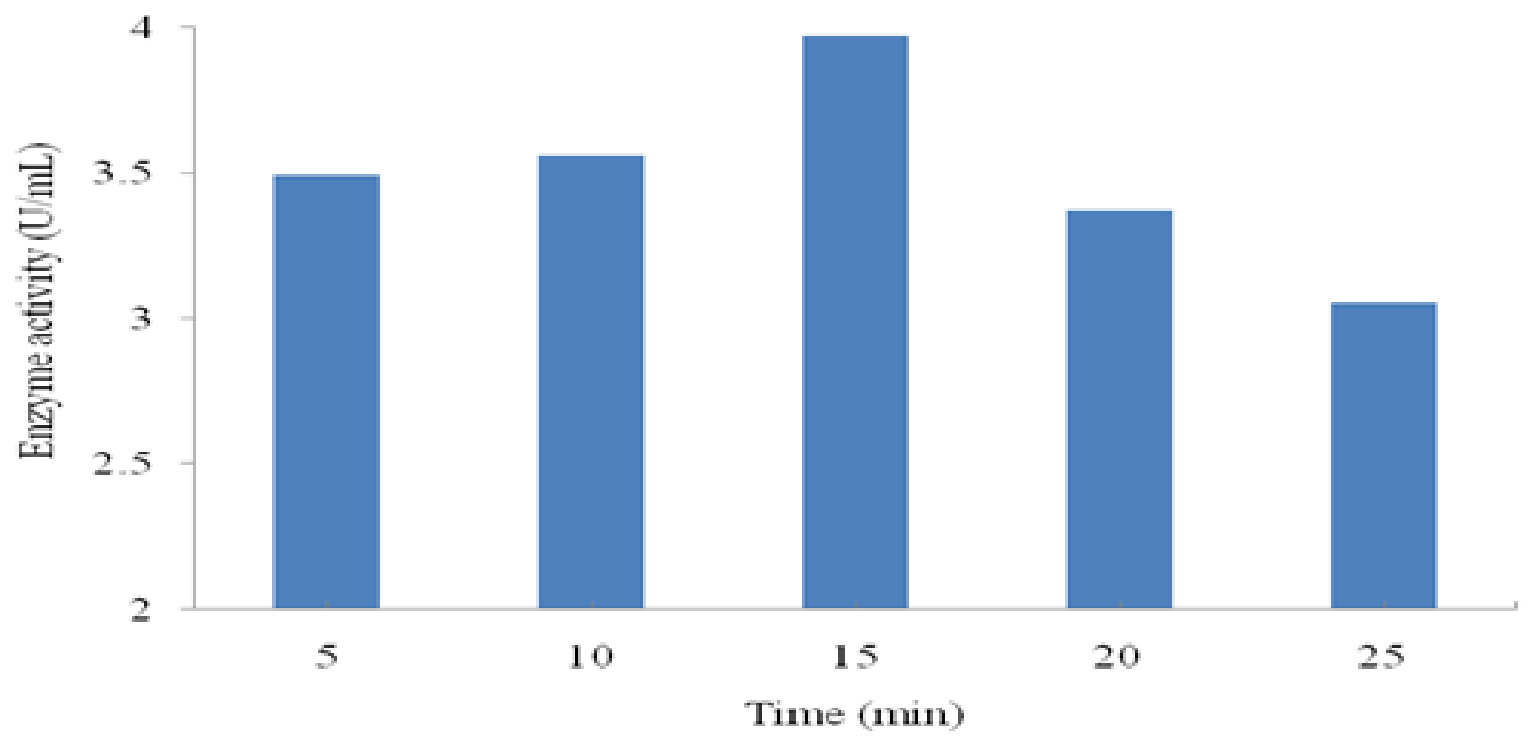


Fig.10 Effect of temperature on lipase activity

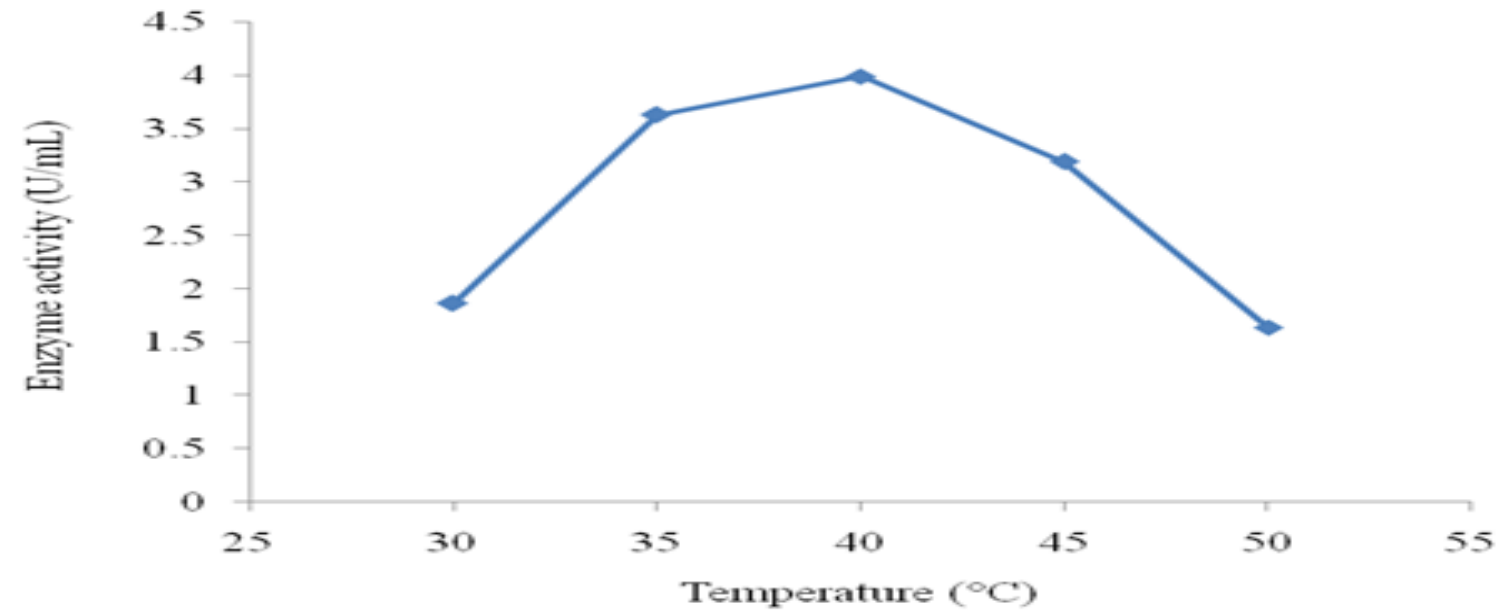

Effect of the concentration of nitrogen source on the production of lipase- Of the various concentrations of peptone used in the production medium, $2.0 \% \mathrm{w} / \mathrm{v}$ showed the maximum enzyme production with an enzyme activity of $3.60 \mathrm{U} / \mathrm{mL}$ (Figure 6). Further increase in concentration led to decrease in enzyme activity. Therefore $2.0 \%$ of peptone was taken as the optimum concentration for further studies. Similarly a research carried out by (Wang et al., 2008) showed maximum lipase production when $2 \%$ of peptone was used as nitrogen source in Micrococcus sp. In another study, $2 \%$ of soyabean powder was optimized as nitrogen source for maximum lipase production from Saccharomyces cerevisiae (Shirazi et al., 1998).

Effect of pH of the medium on production of lipase The production of enzyme is very sensitive to the $\mathrm{pH}$ of the production medium therefore, optimization of $\mathrm{pH}$ is a necessary step for the maximum production of lipases. The maximum production of lipase $(3.69 \mathrm{U} / \mathrm{mL})$ was obtained at $\mathrm{pH}$ of 8.0 (Figure 7). This might be because organism required a slightly basic $\mathrm{pH}$ for its metabolic processes as well as for the production of lipases (Kiran et al., 2008). Increase or decrease in $\mathrm{pH}$ had negative impact on the production of lipase. In another study, Fusariumsolani gave maximum lipase production at $\mathrm{pH}$ of 8.6 (Maia et al., 1999).

Effect of incubation temperature on lipase production- Temperature is known to influence the metabolic rate of the organism involved in the process, which in turn determines the amount of end product. Most favourable temperature for maximum extracellular lipase production $(3.95 \mathrm{U} / \mathrm{mL})$ was found to be $40^{\circ} \mathrm{C}$ (Figure 8). Increase or decrease in temperature from $40^{\circ} \mathrm{C}$ caused a decrease in enzyme production, indicating the mesophilic nature of the isolated strain. High production temperature reduces the contamination risk during fermentation (Madhaiyan and Sundaram 2004). However, a moderate optimal temperature for a longer incubation period is beneficial so as to reduce the cost of production. Maximum lipase production was observed at $25^{\circ} \mathrm{C}$ from Pseudomonas sp. (Kulkarni and Gadre, 2013).

Effect of agitation rate on lipase production - The maximum lipase production was obtained at $150 \mathrm{rpm}$ and was therefore taken as the optimum agitation rate for further studies (Table 4). Higher stirring speeds than 250 $\mathrm{rpm}$ resulted in mechanical and/or oxidative stress, excessive foaming, disruption and physiological disturbance of the cells, while lower stirring speeds seemed to limit oxygen levels along with the lacking of homogeneous suspension of the fermentation medium and breaking of the clumps of the cells. (Elibol and Ozer2000) also reported that main reason for the negative effect of agitation speed might due to the perturbation of protein structure during the biosynthesis of lipase. Agitation rate of $120 \mathrm{rpm}$ was found to give maximum lipase production from Fusarium solani (Maia et al., 1999) and Penicilliumcyclopium (Vanot et al., 2002).

Effect of reaction time on lipase activity - Maximum activity of extracellular lipase $(3.97 \mathrm{U} / \mathrm{mL})$ was observed after 15 minutes of incubation (Figure 9). The longer an enzyme is incubated with its substrate, the greater the amount of product that will be formed. However, the rate of formation of product is not a simple linear function of the time of incubation.Incubation time of 10 minutes gave maximum activity of lipase from Penicilliumsp. in a study carried out earlier (Margesin et al., 2002). 
Effect of reaction temperature on lipase activity Maximum enzyme activity $(3.99 \mathrm{U} / \mathrm{mL})$ was observed at $40^{\circ} \mathrm{C}$ of incubation temperature (Figure 10). When the temperature was increased or decreased from $40^{\circ} \mathrm{C}$ there was a consistent decrease in lipase activity. The optimum temperature for lipase activity was $35^{\circ} \mathrm{C}$ for Penicillium candidum (Ruitz et al., 2001) and $37^{\circ} \mathrm{C}$ for Aspergillus niger (Kamini et al., 1998).

\section{References}

Abdel-Fattah, G.M. and Hammad, I. 2002. Production of lipase by certain soil fungi.Optimization of cultural conditions and genetic characterization of lipolytic strains of Aspergilliusing protein patterns and random amplified polymorphic DNA (RAPD).Online. J. Biol. Sci; 2: 639-644.

Castro, H.F., Mendes, A.A., and Santos, J.C. 2004. Modificac,a $a^{\sim}$ de $\mathrm{o}^{\prime}$ leos e gordurasporbiotransformaca o. Qu1'mica Nova, 27, 146D156.

Cihangir, N. and Sarikaya, E. 2004. Investigation of lipase production by a new isolated of Aspergillus sp. World J. Microbiol.Biotechnol., 20: 193-197.

Colen, G., Junqueira, R.G.A. and Moraes-Santos, T. 2006. Isolation and screening of alkaline lipaseproducing fungi from Brazilian savanna soil. World. J. Micro-Biot., 22: 881-885.

Elibol, M. and Ozer, D. 2000. Lipase production by immobilized Rhizopusarrhizus. Process Biochem., 36: 219-223.

Elibol, M. and Ozer, D. 2001. Influence of oxygen transfer on lipase production by Rhizopusarrhizus. Process Biochem., 36: 325-9.

Elibol, M. and Ozer, D. 2000. Influence of oxygen transfer on lipase production by Rhizopusarhizus. Process Biochem., 36: 325D329.

Espinosa, E., Sanchez, S. and Farres, A. 1990.Nutritional factor affecting lipase production. Biotechnol. Lett., 12: 209-214.

Fadiloglu, S. and Erkmen, O. 2002. Effects of carbon and nitrogen sources on lipase production by Candida rugosa. Turk. J. Eng. Env. Sci., 26: 249254.

Gopinath, S.C.B., Anbu, P., Lakshmipriya, T. and Hilda, A. 2013. Strategies to characterize fungal lipases for applications in medicine and dairy industry.Bio Med. Res. Intl; 10: 1155-1165.

Gupta, R., Gupta, N. and Rathi, P. 2004. Bacterial lipases: an overview of production, purification and biochemical properties. App. Microb. Biot., 64: 763-781.
Hasan, F., Shah, A. A., and Hameed, A. 2006. Industrial applications of microbial lipases. Enzyme Microb.Technol., 39: 235D251.

Hiol, A., Jonzo, M.D., Rugani, N., Druet, D., Sarda, L. and Comeau, L.C. 2000. Purification and characterization of an extracellular lipase from a thermophilicRhizopus oryzae strain isolated from palm fruit. Enzyme. Microb. Techno., 26: 421-30.

Jagdish Chander. 2009. Text Book of Medical Mycology $3^{\text {rd }}$ edition. Maheta publication, 350-352.

Kamini, N.R., Fujii, T., Kurusu, T. and Iefuji, H. 2000. Production, purification and characterization of extracellular lipase from yeast, Cryptococcus sp. S2. Process Biochem., 36: 317-324.

Kekde, R.B. and Chavan, A.M. 2011. Extracellular Lipase Enzyme Production by Seed-Borne Fungi under the Influence of Physical Factors. Intl. J. Bio., 3: 124-131.

Kempka, A.P., Lipke, N.R., Pinheiro, T.L.F., Menoncin, S., Treichel, H. and Freire, D.M.G. 2008. Response surface method to optimize the production and characterization of lipase from Penicilliumverrucosum in solid-state fermentation. Bioprocess Biosyst. Eng., 31: 119-125.

Kiran, G.S., Shanmughapriya, S., Jayalakshmi, J., Selvin, J., Gandhimathi, R. and Sivaramakrishnan, S. 2008. Optimization of extracellular psychrophilic alkaline lipase produced by marine Pseudomonas sp. MSI057. Bioprocess Biosyst. Eng., 31: 483-492.

Kim, E.K., Jang, W.H., Ko, J.H., Kang, J.S., Noh, M.J., Yoo, O.J. 2001. Lipase and its modulator from Pseudomonas sp. strain KFCC 10818: proline-toglutamine substitution at position 112 induces formation of enzymatically active lipase in the absence of the modulator. J. Bacteriol., 183(20): 5937-5941.

Kulkarni, N. and Gadre, R.V. 2002. Production and properties of an alkaline,thermophilic lipase from Pseudomonas fluorescens NS2W. J. Ind. Microbiol. Biotechnol., 28: 344-348.

Lacointe, C., Dubreucq, E. and Galzy, P. 1996. Ester synthesis in aqueous media in the presence of various lipases.Biotechnol.Lett., 18: 869-74.

Lutz, S. 2004. Engineering lipase B from Candida antarctica. Tetrahedron Asymmetry; 15(18):27432748.

Madhaiyan, M. and Sundaram, S.P. 2004. Occurrence of thermostable pectin degrading fungi on decayed fruits and vegetables. Asian J. Microbiol. Biotechnol. Environ. Sci., 6: 363-366.

Mahadik, N. D., Puntambekar, U. S., Bastawde, K. B., Khire, J. M., and Gokhale, D. V. 2002. Production 
of acidic lipase by Aspergillus niger in solid state fermentation, Process Biochem., 38, 715D721.

Maia, M. M. D., Heasley, A., Camargo de Morais, M. M., Melo, E. H. M., Morais, Jr. M. A., Ledingham, W. M., and Lima Filho, J. L. 2001. Effect of culture conditions on lipase production by Fusariumsolaniin batch fermentation. Biores.Technol., 76, $23 \mathrm{D} 27$.

Maia, M.M.D., Morais, M.M.C.D., Melo, E.H.M. and Filho, J.L.D.L. 1999. Production of extracellular lipase by the phytopathogenic fungusFusariumsolani. FS1. Rev. Microbiol., 30: 304-309.

Margesin, G., Feller, G., Hammerle, M., Stegner, U. and Schinner, F. 2002. A colorimetric method for the determination of lipase activity in soil. Biotechnol. Lett., 24:27-33.

Mathew, A., Eldo, A.N. and Molly, A.G. 2008. Optimization of culture conditions for the production of thermostablepolygalacturonase by Penicillium SPC-F 20. J. Ind. Microbiol. Biotechnol., 35: 1001-1005.

Mendes, A.A., Castro, H.F., Pereira, E.B. and Furigo, J.R. A. 2005. Aplicação de lipases no tratamento de águasresiduárias com elevadosteores de lipídeos. Quím Nova, 28: 296-305.

Mukeshkumar, D.J., Lawrence, L., Rajan, R., Priyadharshini, S., Sandhiya chittybabu, Kalaichelvan, P.T. 2012a. Characterization of lipase and protease from Serratia marcescens DEPTK21 and its destaining capability. Asian J. Exp. Biol. Sci., 3: 621-628.

Mukeshkumar, D.J., Priyadharshini, D.A., Suresh, K., Saranya, G.M., Rajendran, K., Kalaichelvan, P.T. 2012b. Production, purification and characterization of _-amylase and alkaline protease by Bacillus sp. HPE 10 in a concomitant production medium. Asian J. Plant Sci. Res., 2: 376-382.

Pahoja, W.M., Sethar, M.A. 2002. A review of enzymatic properties of lipase in plants, animals and microorganisms. J. Appl. Sci., 2: 474-84.

Pratuangdejkul, J., Dharmsthiti, S. 2000. Purification and characterization of lipase from psychrophilic
Acinetobacter calcoaceticus LP009. Microbiol Res., 155: 95-100.

Rao, P. V., Jayaraman, K., and Laksahmanan, C.M. 1993. Production of lipase by Candida rugosain solid state fermentation 1: Determination of significant process variables. Process Biochem., 31, 669D678.

Ruitz, B., Farres, A., Langley, E., Masso, F. and Sanchez, S. 2001. Purification and characterization of an extracellular lipase from Penicillium candidum. Lipids, 36: 283-289.

Sharma, R., Chisti, Y., and Banerjee, Y.C. 2001. Production, purification, characterization and applications of lipases. Biotechnol. Adv., 19, 627D662.

Sharma, S., Shrestha, A. and Rai, B. 2012. Screening, optimization and pilot scale production of enzyme lipase in a bioreactor from Aspergillus species, A project report. Min. Sci. Tech., Nepal.

Shirazi, S.H., Rahman, S.R. and Rahman, M.M. 1998. Production of extracellular lipases by Saccharomyces cerevisiae. World. J. Microb. Biot., 14: 595-597.

Sneath, P.H.A. 1986. Bergeys manual of determinative Bacteriology.2nd ed. Baltimore: Wiliams and Wilkins eds; 1105-1138.

Sztajar, H. and Maliszewska, I. 1988. The effect of culture conditions on lipolytic productivity of microorganism. Biotech. Lett., 10: 199-204.

Ul-Haq, I., Idrees, S., and Rajoka, M. 2002. Production of lipases by Rhizopusoligosporusby solid-state fermentation. Process Biochem., 37, 637D341

Vanot, G., Valerie, D., Guilhem, M.C., Phan, T.L.R. and Comeau, L.C. 2002. Maximizing production of Penicilliumcyclopium partial acyl glycerol lipase. Appl. Microbiol., 60: 417-419.

Wang, Y., Gao, S., Wang, T., Luo, G., Dai, Y. 2008. Immobilization of lipase on methyl modified silica aerogels by physical adsorption. Biores. Technol., 100: 996-999.

Winkler, U.K., Stuckmann, M. 1997. Glycogen, hyaluronateand some other polysaccharides greatly enhance theformation of exolipase by Serratia marcescens. J. Bacteriol., 138(3): 663-670.

\section{How to cite this article:}

Gaurav Kumar, Sameer Singh Faujdar, Priya Mehrishi, Shikha Sharma. 2017. Screening and Optimization of Filamentous Fungi for Extracellular Lipase Production from Various Soil Samples Taken In and Around Shimla. HP), India. Int.J.Curr.Res.Aca.Rev. 5(1), 42-53. doi: http://dx.doi.org/10.20546/ijcrar.2017.501.005 